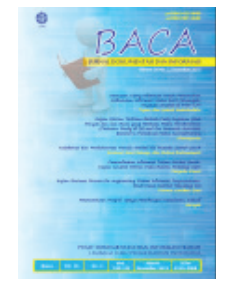

\title{
PENGALAMAN MAHASISWA DALAM MELAKUKAN WIRAUSAHA INFORMASI: SEBUAH PENELITIAN GROUNDED THEORY
}

\author{
Afdini Rihlatul Mahmudah ${ }^{1 *}$, Hariyah ${ }^{2}$ \\ ${ }^{1,2}$ Pasca-Sarjana Program Studi Ilmu Perpustakaan, Universitas Indonesia \\ *Korespondensi: afdinirm@gmail.com
}

Diajukan: 5-3-2016; Direview: 15-6-2016; Diterima: 10-8-2016; Direvisi: 5-10-2016

\begin{abstract}
The main focus of this paper is to explore students' understanding of information entrepreneurship. This is a qualitative study using grounded theory. Selection of the method is based on research conducted purpose, namely to build a theory based on the views of respondents. The steps taken to obtain the data are interviews, observation, and document review. The data is analyzed based on data analysis model constructivism form of transcription of data and interpretation of data through open coding, axial coding, and selective coding. Because that's grounded theory meant to know in depth understanding of information entrepreneurship is mainly done by the students. The study also covers entrepreneurship and entrepreneurial activity information extracted information from the perspective of students. The conclusion of this study is an entrepreneur information definition. That definition is work in the field of information that can be done independently or in groups, with flexibility in the time and place of the work, in the form of search activity information, creating web and library systems, consulting libraries, teachers, and librarians to make money, add experience and knowledge, as well as develop social activities.
\end{abstract}

\begin{abstract}
ABSTRAK
Fokus utama dari tulisan ini adalah menggali pemahaman mahasiswa tentang wirausaha informasi. Penelitian ini bersifat kualitatif dengan menggunakan grounded theory. Pemilihan metode ini didasarkan pada tujuan penelitian yang dilakukan, yaitu membangun teori berdasarkan pandangan responden. Langkah-langkah yang dilakukan untuk memperoleh data adalah wawancara, observasi, dan kajian dokumen. Data tersebut dianalisis berdasarkan model analisis data konstruktivisme berupa transkripsi data dan interpretasi data melalui pengkodean terbuka (open coding), pengkodean beralas (axial coding), dan pengkodean terseleksi (selective coding). Karena itulah grounded theory dimaksudkan untuk mengetahui secara mendalam pengertian wirausaha informasi terutama yang dilakukan oleh mahasiswa. Penelitian meliputi pengertian wirausaha informasi dan aktivitas wirausaha informasi yang digali dari sudut pandang mahasiswa. Kesimpulan yang diperoleh dari penelitian ini adalah sebuah definisi wirausaha informasi. Definisi tersebut adalah pekerjaan dalam bidang informasi yang dapat dilakukan, baik secara mandiri maupun berkelompok, dengan fleksibilitas dalam waktu dan tempat pengerjaannya, berupa kegiatan pencarian informasi, pembuatan web dan sistem perpustakaan, konsultan perpustakaan, pengajar, dan pustakawan sehingga menghasilkan uang, menambah pengalaman dan ilmu, serta mengembangkan aktivitas sosial.
\end{abstract}

Keywords: Information entrepreneurship; Grounded theory; Entrepreuner 


\section{PENDAHULUAN}

Saat ini ada sebagian mahasiswa bahkan sarjana-sarjana yang baru lulus mengalami kebingungan saat mereka menyelesaikan studinya. Mereka belum memiliki atau belum sepenuhnya mampu menguasai keterampilan atau keahlian yang dibutuhan di dunia kerja. Hal ini terjadi di antaranya karena belum ada sebuah sistem yang baik dan saling terhubung antara dunia pendidikan dan dunia kerja serta interpreneurship atau jiwa kewirausahaan mahasiswa yang belum terbangun.

Kondisi semacam ini dipaparkan oleh Khumalo dan Nkala (2015:66) bahwa "universities usually do not have proper marketing structures that "sell" students and programmes to the industry. Therefore, the growth and development of a new degree programme is dependent on its meeting industry and market demands and creativity, innovativeness and groundbreaking initiatives". Dapat dikatakan bahwa universitas biasanya tidak memiliki struktur pemasaran yang tepat yang mampu "menjual" mahasiswa dan program pendidikannya untuk industri. Oleh karena itu, pertumbuhan dan pengembangan sebuah program pendidikan baru tergantung kreativitas, inovasi, dan inisiatif dalam memenuhi permintaan industri dan pasar. Dikatakan pula bahwa "university graduates have been popular for being loaded with theory, yet failing to practic" (Khumalo dan Nkala, 2015: 69). Artinya, masih banyak sarjana yang hanya mampu pada tataran teori, namun tidak memiliki banyak kemampuan atau gagal dalam mempraktikkan ilmunya atau menjawab kebutuhan dunia industri.

Salah satu solusi yang ditawarkan dalam menghadapi situasi tersebut adalah dengan membangun jiwa wirausaha informasi pada mahasiswa. Sebagai contoh, wirausaha informasi yang terkait dengan bidang perpustakaan dan informasi. Sebagaimana pernah diungkapkan oleh du Toit (2000:84) dalam Ramugondo (2010), yaitu "infopreneurship will create dynamic graduates who are flexible enough and can adapt to changes and demands in the marketplace. Today, information specialists are compelled to use new skills and strategies in order to change, survive, and continue to compete in the world of virtual information technologies are being developed on a daily basis, and infopreneurs who survive will be the ones who will be able to flow with change and proactively harness these changes and turn them to profitable business ideas and ventures".

Dari pernyataan di atas dapat dikatakan bahwa infopreneurship akan menciptakan lulusan yang dinamis yang cukup fleksibel dan dapat beradaptasi dengan perubahan dan tuntutan pasar. Saat ini, spesialis informasi dipaksa untuk menggunakan keterampilan dan strategi baru agar mampu mengubah, bertahan hidup, dan terus bersaing dalam dunia teknologi informasi virtual yang sedang berkembang setiap hari. Infopreneurs yang mampu bertahan akan menjadi orangorang yang dapat mengikuti perubahan dan proaktif memanfaatkan perubahan dengan menciptakan ide-ide usaha dan usaha yang menguntungkan.

Pernyataan tersebut diperkuat oleh Khumalo dan Nkala (2015:74) bahwa "preparing students for employment is becoming less viable and thus students and or graduates need to be trained to create jobs and significantly contribute to the growth of economies. Furthermore, training has to go beyond theory and equip students with practical skills". Dapat dikatakan bahwa persiapan mahasiswa atau para sarjana masih belum optimal dalam memasuki dunia kerja karena itulah mahasiswa atau sarjana perlu dilatih untuk menciptakan lapangan kerja sehingga secara signifikan berkontribusi pada pertumbuhan ekonomi. Selanjutnya, pelatihan tersebut harus melampaui teori dan membekali siswa dengan keterampilan praktis yang menunjang.

Dewiyana (2006:28) pernah menyebutkan bahwa di negara-negara maju terjadi kecenderungan baru dimana lulusan sarjana ilmu perpustakaan yang memiliki jiwa kewirausahaan (enterpreneurship) membuka usaha di bidang layanan jasa informasi. Mereka menjadi pelaku usaha baru dengan mengemas ulang informasi (information repackage) yang ada ke dalam berbagai bentuk penyajian dan media sehingga memiliki nilai jual yang tinggi, ataupun menawarkan jasa penelusuran informasi ke berbagai sumber atau situs. Upaya itu telah menjadikan informasi sebagai suatu produk yang dapat dijual, baik kepada individu maupun kepada sejumlah organisasi termasuk pelaku dan organisasi usaha.

Terkait beberapa hal yang telah disebutkan di atas, bagaimana sesungguhnya pandangan mahasiswa mengenai wirausaha informasi. Tulisan ini bermaksud menggali pengalaman mahasiswa dalam melakukan wirausaha informasi. Oleh karena itu, pendekatan penelitian 
dilakukan secara kualitatif menggunakan metode grounded theory. Penelitian grounded theory ini berusaha untuk mengembangkan teori tentang wirausaha informasi dari pengalaman mahasiswa yang pernah melakukan kegiatan wirausaha informasi. Rancangan penelitian yaitu melakukan studi pendahuluan untuk mendapatkan gambaran mengenai information entrepreneurship atau wirausaha informasi. Kemudian, melakukan wawancara kepada tujuh responden untuk mendapatkan data-data yang diperlukan dan dua responden untuk diskriminan sampling. Selanjutnya, dilakukan coding sampai pada kesimpulan.

Tujuan dari penelitian ini adalah untuk mengetahui proses pemaknaan wirausaha informasi berdasarkan pengalaman dan kegiatan yang pernah dilakukan oleh mahasiswa Jurusan Ilmu Perpustakaan dan Informasi Universitas Indonesia. Dalam penelitian ini digunakan sudut pandang atau pendekatan konstruktivisme untuk memahami proses pemaknaan wirausaha informasi dalam kegiatan mahasiswa. Pendekatan konstruktivisme yang dimaksud adalah menemukan jawaban terhadap masalah yang diteliti berdasarkan pandangan responden dalam melakukan kegiatan wirausaha informasi.

\section{TINJAUAN PUSTAKA}

\subsection{Wirausaha Mahasiswa}

Wirausaha dapat dimulai dari kalangan generasi muda seperti mahasiswa, Zuraida dan Ayu (2013) dalam tulisannya menyebutkan pengembangan kewirausahaan di kalangan mahasiswa harus memperhatikan karakteristik mahasiswa yang unik dengan perilaku, gaya komunikasi, pola belajar yang khas, dan lingkungan yang unik. Perguruan tinggi sebagai lembaga yang diharapkan mampu membantu pengembangan kewirausahaan di kalangan mahasiswa tentunya harus memperhatikan kendala yang dihadapi mahasiswa dalam memulai kegiatan wirausaha. Pemahaman ini akan diperoleh ketika lembaga tinggi mempunyai pengetahuan mengenai bagaimana sebenarnya perilaku berwirausaha di kalangan mahasiswa. Selain itu, perlu dipahami mengenai minat, perilaku, dan pola pikir yang mengarah kepada kewirausahaan pada umumnya yang dipengaruhi oleh media komunikasi, lingkungan keluarga, dan faktor demografi.

Kendala dimulainya kegiatan berwirausaha di kalangan mahasiswa biasanya dalam hal modal dan waktu untuk melakukan wirausaha. Hasil penelitian yang dilakukan Zuraida dan Ayu (2013) menyebutkan bahwa hampir 70\% dari total jumlah mahasiswa menyatakan bahwa kendala utama belum dimulainya usaha adalah modal dan ketersediaan waktu. Modal berkaitan dengan uang yang diperlukan untuk memulai usaha, sedangkan waktu berkaitan dengan upaya mahasiswa untuk membagi waktu dengan belajar dan mengerjakan tugas sebagai mahasiswa.

Mengembangkan kewirausahaan di kalangan mahasiswa memerlukan pendidikan kewirausahaan yang harus mempertimbangkan teknik mengajar yang diperlukan mahasiswa untuk meningkatkan pola pikir kewirausahaan dan pengalaman melakukan wirausaha. Mahasiswa juga perlu membuat analisis diri pada sikap dan kompetensi kewirausahaan untuk memahami kesiapan sendiri dan kemampuan dalam kewirausahaan. Peterman dan Kennedy (2003) dalam Pihie dan Sani (2009), menyebutkan bahwa pendidikan kewirausahaan telah dipromosikan untuk mendorong perilaku kewirausahaan di perguruan tinggi negeri. Literatur pada program pendidikan kewirausahaan menyarankan agar program ini berhasil mendorong calon pengusaha untuk memulai usaha, atau meningkatkan kinerja usaha. Program tersebut memberikan pengalaman sosial, seperti kesempatan untuk menjalankan tanggung jawab yang signifikan, untuk memulai sendiri usaha dan untuk mengamati model peran yang relevan.

Penelitian yang dilakukan oleh Pihie dan Sani (2009) membuktikan bahwa mahasiswa yang mengikuti pendidikan kewirausahaan dapat memperluas pemahaman kewirausahaannya serta mengeksplor pola pikir mereka untuk meningkatkan kesadaran berwirausaha dan keterampilan berwirausaha. Mereka juga mampu dan memiliki kepercayaan diri untuk memulai usaha sendiri, mereka siap dan termotivasi untuk memulai usaha mereka sendiri. Pendidikan kewirausahaan yang dilakukan menggunakan teknik pengajaran, seperti menjalankan usaha yang nyata, kunjungan ke lokasi usaha, dan wawancara dengan pengusaha. Teknik-teknik pengajaran tersebut dianggap penting dalam 
meningkatkan kesadaran dan keterampilan kewirausahaan mahasiswa.

Pada teknik menjalankan usaha yang nyata, mahasiswa mempunyai tanggung jawab dalam menerima risiko dan manfaat dari mendirikan sebuah usaha. Mereka mendapatkan pengalaman nyata dalam mengumpulkan uang, perencanaan semua fungsi manajemen usaha seperti produksi, pemasaran, dan keuangan. Pada saat yang sama mahasiswa mampu meningkatkan softskill mereka dalam aspek motivasi, kerja tim, jaringan, dan keterampilan hubungan dengan pelanggan. Adapun pada teknik kunjungan ke lokasi usaha, mahasiswa dapat mengamati operasional usaha secara nyata, memperoleh informasi yang dibutuhkan langsung dari pengusaha, memberi kesempatan untuk memahami siapa pengusaha sejati, mendapatkan lebih banyak masukan dan untuk meningkatkan motivasi diri mereka melalui pengalaman pengusaha. Pada teknik wawancara dengan pengusaha, mahasiswa mendapatkan penjelasan mengenai pengalaman usaha mereka, belajar menjadi seorang pengusaha, kisah hidup, kepribadiannya, juga mendapatkan informasi yang tepat terutama pada keberhasilan dan faktor kegagalan dalam berwirausaha.

\subsection{Wirausaha Informasi}

Istilah kewirausahaan sebenarnya bukan istilah baru dalam Ilmu Perpustakaan dan Informasi. Wirausaha informasi berasal dari istilah wirausaha dan informasi. du Toit (2000) dalam Ramugondo (2010) menyatakan wirausaha sebagai usaha dari seseorang yang memobilisasi faktor produksi untuk menghasilkan produk dan jasa, sedangkan informasi didefinisikan sebagai sumber daya. Vaghely dan Julien (2010) menyebutkan informasi yang dikombinasikan dengan pengalaman, konteks, interpretasi, dan refleksi disebut sebagai pengetahuan. Kedua istilah tersebut, wirausaha dan informasi jika digabungkan menunjukkan bahwa terdapat individu yang berada dibelakang seluruh proses yang terjadi untuk menjadi wirausaha informasi dengan produk informasi dan layanan.

Lebih lanjut du Toit (2000:83) dalam Ramugondo (2010), menyatakan bahwa "entrepreneurs are those individuals in societywho take the lead as well as the risk in mobilising the production factors (naturalresources, human resources and capital) inspecific combinations to produce productsand services for their communities". Dapat dikatakan bahwa wirausahawan adalah orang-orang dalam masyarakat yang mampu mengambil risiko dalam memobilisasi faktor produksi (sumber daya alam, sumber daya manusia dan modal) yang dapat dikombinasikan secara spesifik untuk menghasilkan produk dan layanan bagi komunitas mereka. Sementara itu, David dan Dube (2013:262) menyatakan bahwa:

"An entrepreneur is generally identified as a person who has qualities, attributes and competencies that promotecreativity, innovativeness, risk taking, positive thinking; driven by the urge to fully utilise availableopportunities and resources to achieve imagined targets that are not normally envisioned by others. Infopreneurs however, are entrepreneurs who identify opportunities for creating enterprising information-basedbusinesses by identifying knowledge deficiency situations and selling target-based information products andservices, mostly through the internet. Infopreneurs are defined as curious, enthusiasts who have the adventurous and driving urge to undertake intelligent searches on wide ranging information (re)sources and to be able to evaluate, repackage and determine the significance, relevance and value of information and information services which they then sell using internet tools to facilitate and enhance their business".

Dari pernyataan di atas dapat disimpulkan bahwa biasanya seorang wirausahawan adalah orang yang memiliki kualitas dan kompetensi dalam mempromosikan kreativitas, inovasi, pengambilan risiko, dan berpikir positif yang didorong oleh keinginan kuat untuk memanfaatkan peluang dan sumber daya yang tersedia untuk mencapai target yang diinginkan. Infopreneurs adalah wirausahawan yang mampu mengidentifikasi peluang untuk menciptakan usaha berbasis informasi dengan menggunakan internet. Infopreneurs dapat digambarkan juga sebagai seseorang yang memiliki jiwa petualang dan keingintahuan yang besar dalam berselancar di dunia informasi dengan menggunakan internet sehingga dapat meningkatkan usaha mereka.

David dan Dube (2013: 263) mengungkapkan pernyataan yang menyebutkan 
bahwa "infopreneurs understand and keep abreast of the developments in information and communication technologies, and information business systems in order to identify and access relevant sources of information, knowledge andunderstanding, target markets, pricing models and relevant customer network trends. Selection, repackaging,sifting, promoting, and distributing knowledge, usually within a niche market is the business of infopreneurs. Infopreneurs are profit oriented enterprising business people running internet based businesses that enable them to sell their expertise to a world-wide audience, by packaging and marketing their knowledge as information based products, online services, and premium consultancy".

Pernyataan di atas menggambarkan bahwa infopreneurs adalah orang yang memahami dan mengikuti perkembangan teknologi informasi dan komunikasi, sistem informasi usaha, akses sumber informasi yang relevan, pengetahuan dan pemahaman target pasar, model penentuan harga, dan tren jaringan pelanggan yang relevan. Dalam hal ini infopreneurs melakukan seleksi, pengemasan ulang, memilah, mempromosikan, dan mendistribusikan pengetahuan dan keahlian yang dimiliki kepada khalayak di seluruh dunia sebagai produk informasi berbasis layanan online.

Dari beberapa pengertian yang telah dipaparkan sebelumnya, dapat ditarik sebuah benang merah dengan merujuk kepada pernyataan yang diungkapkan oleh Lahm dan Stowe (2010: 55) bahwa "most compelling to the researchers of this paper, is the fact that information productsconsist of aggregated information or are developed based upon a creator's own familiarity with asubject matter, for little or no cost. In effect, much like blogging has democratized mass mediaby empowering the public at large to serve as news gatherer-reporters, analysts, and critics,revolution in the information products industry is having ripple-effects in the shadow of themainstream publishing industry". Selain itu, hal yang paling menarik dari tulisan ini adalah fakta bahwa produk informasi terdiri dari informasi yang dikumpulkan atau dikembangkan berdasarkan keakraban pencipta sendiri dengan materi pelajaran yang sedikit atau tanpa biaya. Salah satu contoh adalah blogging, sebagai salah satu bentuk demokratisasi media massa yang telah memberdayakan masyarakat luas sebagai pengumpul berita, dalam hal ini di antaranya wartawan, analis, dan kritikus berita yang merupakan bagian dari revolusi dalam industri produk informasi.

\subsection{Kegiatan Wirausaha Informasi}

David dan Dube (2013: 262) menyatakan "young people's potential to create outstanding information content businesses relies on their education which informs their behaviour as they engage in the information business. University education is a typical knowledge imparting platform from where young people can get infopreneurship education to start viable infopreneurship businesses". Dari pernyataan tersebut dapat diartikan bahwa orang-orang muda sangat berpotensi menciptakan usaha konten informasi, tetapi hal ini sangat tergantung dari pendidikan yang mereka miliki terkait wirausaha informasi. Pendidikan di universitas semestinya dapat diandalkan untuk memberikan pengetahuan dan platform yang jelas sehingga mahasiswa bisa mendapatkan pendidikan infopreneurship untuk memulai usaha infopreneurship mereka yang layak.

Menurut Ocholla (1999), area wirausaha informasi mengacu pada proyek-proyek yang mungkin dilakukan jika seseorang memutuskan untuk mengejar infopreneurship. Bidang-bidang tersebu, antara lain: penelitian (eksplorasi dan evaluatif) di bidang informasi dan bidang terkait, seperti kajian pengguna, kompilasi daftar bibliografi, penyediaan informasi usaha saat ini, kompilasi direktori, penerbitan, jasa terjemahan, pengemasan ulang informasi, menulis, mengedit dan membaca bukti manajemen, manajemen koleksi, rekaman, dan katalogisasi. Bidang-bidang tersebut merupakan bidang dalam kegiatan wirausaha informasi. Adapula bidang infopreneurship yang dapat diidentifikasi, seperti penyedia internet, e-services, dan m-services.

David dan Dube (2013: 267) menyebutkan bahwa mahasiswa jurusan Ilmu Perpustakaan dan Informasi dapat menggarap bidang-bidang wirausaha informasi, seperti: (1) novel, short story, poetry writing; (2) publishing projects consultancy; (3) graphic designing services; (4) knowledge management consultancy; (5) web/content analyst; (6) 
educational publishing; (7) authorship; (8) marketing company information products; dan (9) book and print media selling \& marketing. Menurutnya, "these graduates have a high understanding of marketing information products. However they indicate that they fall short on bringing their businesse". Dapat dikatakan bahwa pada bidang-bidang tersebut lulusan ini memiliki pemahaman yang tinggi tentang pemasaran produk informasi, namun masih jatuh bangun dalam membangun wirausaha informasi mereka.

\subsection{Grounded Theory}

Berbeda dengan pembahasan sebelumnya, bagian ini menguraikan secara singkat mengenai grounded theory, sebagai metode penelitian kualitatif yang digunakan dalam penelitian ini. Creswell (2011) menyatakan bahwa grounded theory adalah sebuah desain sistematis, prosedur kualitatif yang digunakan untuk menghasilkan sebuah teori yang menjelaskan, pada tingkat konseptual yang luas, proses, tindakan, atau interaksi tentang topik substantif. Selanjutnya, Pendit (2003) menyatakan bahwa dalam prinsip grounded theory, semua teori harus didasarkan pada data kualitatif yang bermutu. Selain itu, semua kegiatan penelitian grounded theory harus dituntun oleh data di lapangan.

Creswell (1998) menyebutkan beberapa ciri utama dari grounded theory, di antaranya: (1) studi grounded theory meneliti aksi atau gerakan yang berusaha dijelaskan oleh peneliti; (2) peneliti berusaha mengembangkan teori tentang proses atau aksi tersebut; (3) memoing menjadi bagian dari pengembangan teori ketika peneliti menuliskan ide berdasarkan data yang telah dikumpulkan dan dianalisis; dan (4) bentuk utama dari pengumpulan data adalah wawancara yang penelitinya secara konstan membandingkan data yang dikumpulkan dari para partisipan dengan ide tentang teori baru.

\section{METODE}

Penelitian ini menggunakan pendekatan kualitatif dengan metode grounded theory. Pemilihan metode ini didasarkan pada tujuan penelitian yang dilakukan, yaitu membangun teori berdasarkan pandangan responden (Mulyana, 2001). Data dalam penelitian ini diperoleh dengan menggunakan wawancara semi-terstruktur (semi-structured interview). Responden adalah mahasiswa S1 angkatan 2011 dan mahasiswa S2 angkatan 2014 Jurusan Ilmu Perpustakaan dan Informasi Fakultas Ilmu Pengetahuan Budaya Universitas Indonesia.

Sampel yang digunakan adalah sampel teoritis, yaitu menentukan sampel berdasarkan kepentingan peneliti untuk menemukan suatu teori. Sampel dalam penelitian ini adalah responden sebagai sumber data yang berjumlah 9 orang. Selain melalui wawancara, data diperoleh berdasarkan observasi dan kajian dokumen. Data tersebut dianalisis berdasarkan model analisis data konstruktivisme dengan melalui transkripsi data, interpretasi data melalui pengkodean terbuka (open coding), pengkodean beralas (axial coding), dan pengkodean terseleksi (selective coding). Analisis data dilakukan melalui tiga tahap, yaitu:

- Tahap 1: Membuat transkrip hasil wawancara yang disusun per pertanyaan sesuai dengan jawaban dari responden.

- Tahap 2: Peneliti mencari makna dalam beragam kata dari responden untuk menentukan kategori.

- Tahap 3: Membuat coding, yaitu: 1) open coding; 2) axial coding; dan 3) selective coding.

- Pembentukan teori dilakukan dengan membuat analisis data komparatif berdasarkan tematema dan kategori inti yang dihasilkan dari proses pengkodean, dan komparasi berdasarkan tujuan penelitian. Penelitian ini dilakukan di Fakultas Ilmu Pengetahuan Budaya Universitas Indonesia.

\section{HASIL DAN PEMBAHASAN}

Grounded theory merupakan desain yang baik digunakan ketika tidak didapatkan teori untuk menjelaskan atau memahami suatu proses, dalam hal ini untuk memahami teori tentang wirausaha informasi yang dibangun dari pikiran, pengalaman, dan kegiatan mahasiswa Jurusan Ilmu Perpustakaan dan Informasi Universitas Indonesia. Hasil dari penelitian ini diperoleh data dari dua kali wawancara, kemudian dari hasil wawancara tersebut dibuatkan open coding. Dalam tahap open coding, peneliti mempelajari transkrip wawancara, catatan lapangan, dan dokumen 
untuk memperoleh kategori informasi yang menonjol yang didukung oleh pengumpulan data tersebut.

Peneliti berusaha menjenuhkan kategori, tujuannya adalah untuk menyajikan kategori itu dengan terus mengamati dan mewawancarai hingga informasi baru yang diperoleh tidak menyediakan pemahaman lebih lanjut ke dalam kategori itu. Kategori tersusun dari subsubkategori yang menyajikan beragam perspektif tentang kategori tersebut. Ini merupakan proses mereduksi data menjadi serangkaian kecil tema atau kategori yang mencirikan proses atau aksi yang sedang diteliti dalam penelitian ini, yaitu mengenai teori tentang wirausaha informasi.

\subsection{Open Coding}

Berikut adalah open coding dari wawancara yang pertama dan wawancara yang kedua.

Tabel 1. Open Coding Wawancara 1 dan Wawancara 2

\begin{tabular}{|c|c|}
\hline Open coding wawancara 1 & Open coding wawancara 2 \\
\hline $\begin{array}{l}\text { A. Melakukan kegiatan pengolahan } \\
\text { - } \quad \text { Klasifikasi (3) } \\
\text { - } \quad \text { Input metadata ke database ( } 3 \text { ) } \\
\text { - } \quad \text { Penentuan tajuk subjek (2) } \\
\text { - Shelving (4) }\end{array}$ & $\begin{array}{l}\text { A. Penelusuranbahan digital } \\
\qquad \quad \text { Pencarian e-book dan e-jurnal (1) }\end{array}$ \\
\hline $\begin{array}{l}\text { B. Fleksibilitas waktu } \\
\text { • Tidak bisa membagi waktu (2) } \\
\text { • Kuliah (2) }\end{array}$ & $\begin{array}{l}\text { B. Pengolahan bahan digital } \\
\text { - Alih media dan input metadata (1) } \\
\text { - Pembuatan web (1) } \\
\text { - Pembuatan sistem perpustakaan }\end{array}$ \\
\hline $\begin{array}{l}\text { C. Keterbatasan pengetahuan } \\
\qquad \quad \text { Kesulitan menentukan subjek (2) }\end{array}$ & 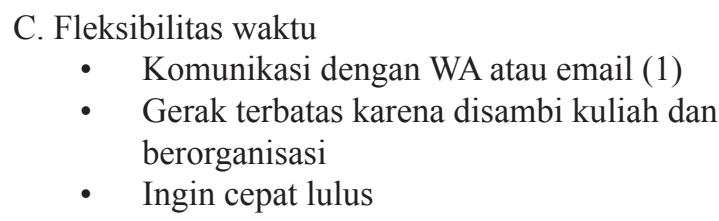 \\
\hline $\begin{array}{l}\text { D. Penghasilan } \\
\qquad \quad \text { Honor (4) }\end{array}$ & $\begin{array}{cc}\text { D. Penghasilan } \\
\qquad \quad \text { Honor (2) } \\
\text { • } & \text { Jejaring (1) } \\
\end{array}$ \\
\hline $\begin{array}{ll}\text { E. Aktualisasi diri } \\
\qquad \quad \text { Pengalaman (4) } \\
\cdot \quad \text { Pengaplikasian ilmu (1) }\end{array}$ & 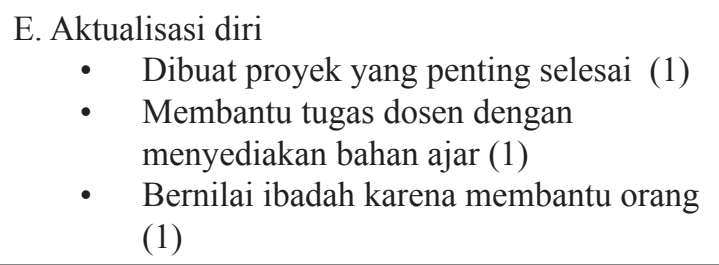 \\
\hline $\begin{aligned} & \text { F. Cita-cita/harapan } \\
&$\[ \quad \text { Meneruskan usaha keluarga (1) } \]$ \\
& \text { - } \text { Membuat perpustakaan untuk } \\
& \text { masyarakat (1) } \\
& \text { - Menjadi pustakawan/arsiparis } \\
& \text { (2) } \\
& \text { - Informasi proyek dari jejaring (4) }\end{aligned}$ & 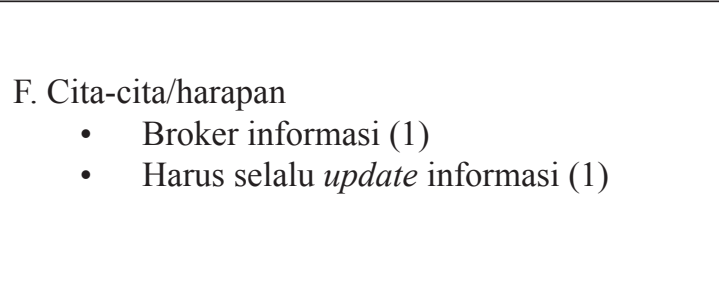 \\
\hline
\end{tabular}

Dalam open coding, peneliti membentuk kategori informasi dengan menyegmentasi informasi. Pada masing-masing kategori, peneliti menemukan beberapa subkategori. kemudian mencari data untuk memperlihatkan secara maksimal rangkaian dari subkategori tersebut. Ketika serangkaian kategori telah dikembangkan, peneliti kemudian mengidentifikasi kategori tunggal dari daftar open coding sebagai fenomena sentralnya. Kategori tersebut adalah kategori yang banyak dibahas oleh para responden, dalam hal ini melakukan kegiatan shelving dalam pengolahan, penghasilan, aktualisasi diri (pengalaman), 
dan harapan (informasi proyek dari jejaring).

Pertanyaan penelitian yang diajukan kepada responden diarahkan untuk memahami bagaimana mahasiswa mengalami proses atau aksi dari kegiatan wirausaha informasi dan mengidentifikasi tahap dalam proses tersebut. Tahap ini dimulai dengan mengeksplorasi persoalan, peneliti kemudian beralih kepada para responden dengan mengajukan pertanyaan yang lebih detail yang akan membantu membentuk tahap axial coding. Tujuannya adalah untuk mengumpulkan sebanyak mungkin informasi agar dapat sepenuhnya mengembangkan atau menjenuhkan modelnya.

\subsection{Axial Coding}

Setelah melakukan open coding, kemudian peneliti melakukan axial coding yaitu pemetaan terhadap gagasan utama. Dalam proses axial coding, peneliti mengulas data untuk menyediakan pengetahuan tentang pengodean kategori spesifik yang berkaitan dengan atau menjelaskan fenomena sentral. Informasi dari tahap axial coding ini kemudian diorganisasikan kedalam bagan yang menampilkan model teoritis dari proses wirausaha informasi. Gambar 1 merupakan hasil coding-nya.

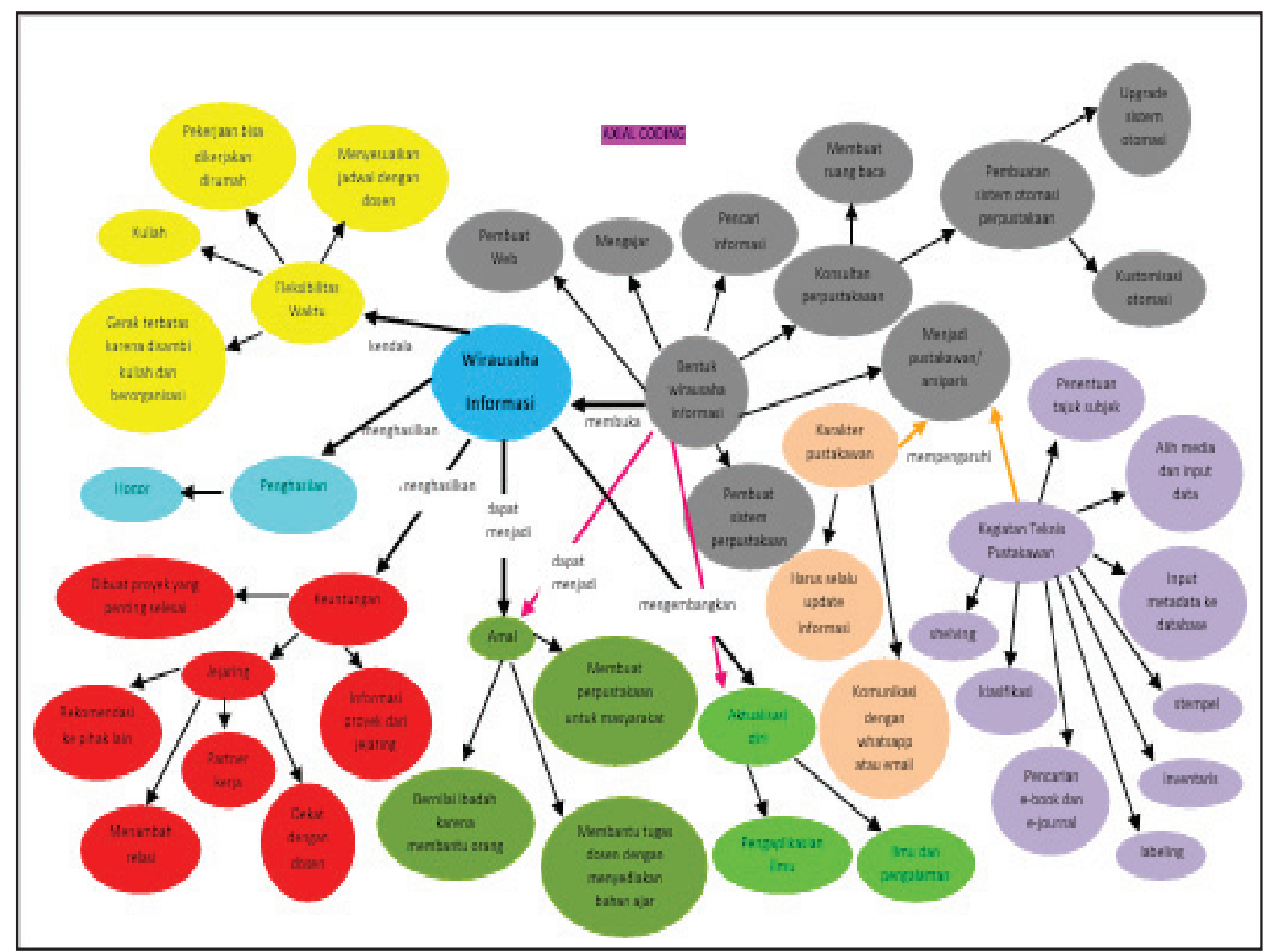

Gambar 1. Hasil coding tahap axial coding

Pada Gambar 1 peneliti menyajikan paradigm coding atau model visual, di mana peneliti mengidentifikasi kategori sentral tentang fenomena wirausaha informasi, mengeksplorasi kategori dari kondisi yang memengaruhi fenomena wirausaha informasi, menentukan aksi atau interaksi yang dihasilkan dari kategori sentral, mengidentifikasi konteks, dan menggambarkan hasil dari aksi atau interaksi fenomena wirausaha informasi. Selanjutnya, peneliti menuliskan alur yang menghubungkan beberapa kategori. Dari cara ini teori dibentuk, kemudian dari teori tersebut peneliti membuat hipotesis atau pernyataan yang saling menghubungkan kategori dalam paradigm coding tersebut. Kategori ini disebut sebagai tahap selected coding. 


\subsection{Selected Coding}

Berikut ini adalah selected coding dari wawancara pertama dan wawancara kedua.

Tabel 2. Selected Coding dari Wawancara 1 dan Wawancara 2

\begin{tabular}{|c|c|}
\hline $\begin{array}{cl}\text { A. Melakukan kegiatan pengolahan } \\
\text { - } \\
\text { - } \quad \text { Inpusifikasi (3) } \\
\text { - } \quad \text { Penentadata ke database (3) } \\
\text { - } & \text { Shelving (4) }\end{array}$ & $\begin{array}{l}\text { A. Penelusuran bahan digital } \\
\text { - Pencarian } e \text {-book dan } e \text {-jurnal (1) }\end{array}$ \\
\hline 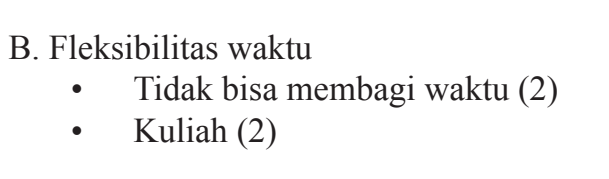 & $\begin{array}{l}\text { B. Pengolahan bahan digital } \\
\text { - Alih media dan input metadata (1) } \\
\text { - Pembuatan web (1) } \\
\text { - Pembuatan sistem perpustakaan }\end{array}$ \\
\hline $\begin{array}{l}\text { C. Keterbatasan pengetahuan } \\
\qquad \quad \text { Kesulitan menentukan subjek (2) }\end{array}$ & $\begin{array}{l}\text { C. Fleksibilitas waktu } \\
\text { - Komunikasi dengan WA atau } \\
\text { email (1) } \\
\text { Gerak terbatas karena disambi } \\
\text { kuliah dan berorganisasi } \\
\text { Ingin cepat lulus }\end{array}$ \\
\hline $\begin{array}{l}\text { D. Penghasilan } \\
\qquad \quad \text { Honor (4) }\end{array}$ & $\begin{array}{l}\text { D. Penghasilan } \\
\begin{array}{ll} & \text { Honor (2) } \\
\text { - } & \text { Jejaring (1) }\end{array}\end{array}$ \\
\hline $\begin{array}{l}\text { E. Aktualisasi diri } \\
\begin{aligned} \text { - } & \text { Pengalaman (4) } \\
\text { - } & \text { Pengaplikasian ilmu (1) }\end{aligned}\end{array}$ & $\begin{array}{l}\text { E. Aktualisasi diri } \\
\text { - Dibuat proyek yang penting } \\
\text { selesai (1) } \\
\text { Membantu tugas dosen dengan } \\
\text { menyediakan bahan ajar (1) } \\
\text { Bernilai ibadah karena membantu } \\
\text { orang (1) }\end{array}$ \\
\hline 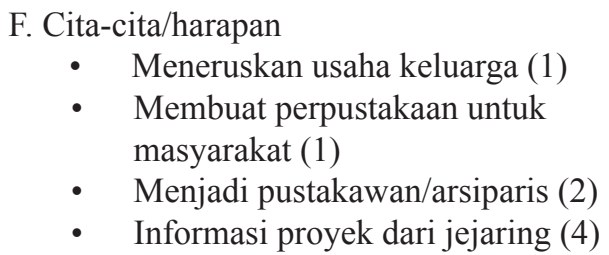 & 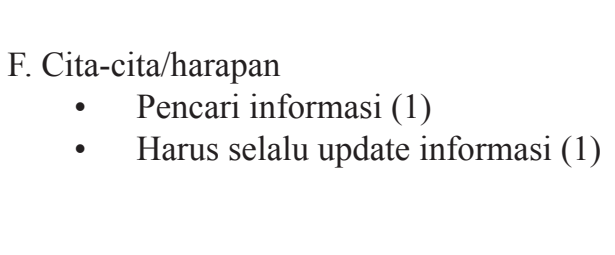 \\
\hline
\end{tabular}


Berdasarkan Tabel 2, peneliti melakukan pengelompokan gagasan yang se-ide, dengan hasil sebagai berikut.

Tabel 3. Pengelompokan Gagasan Se-ide pada Selected Coding

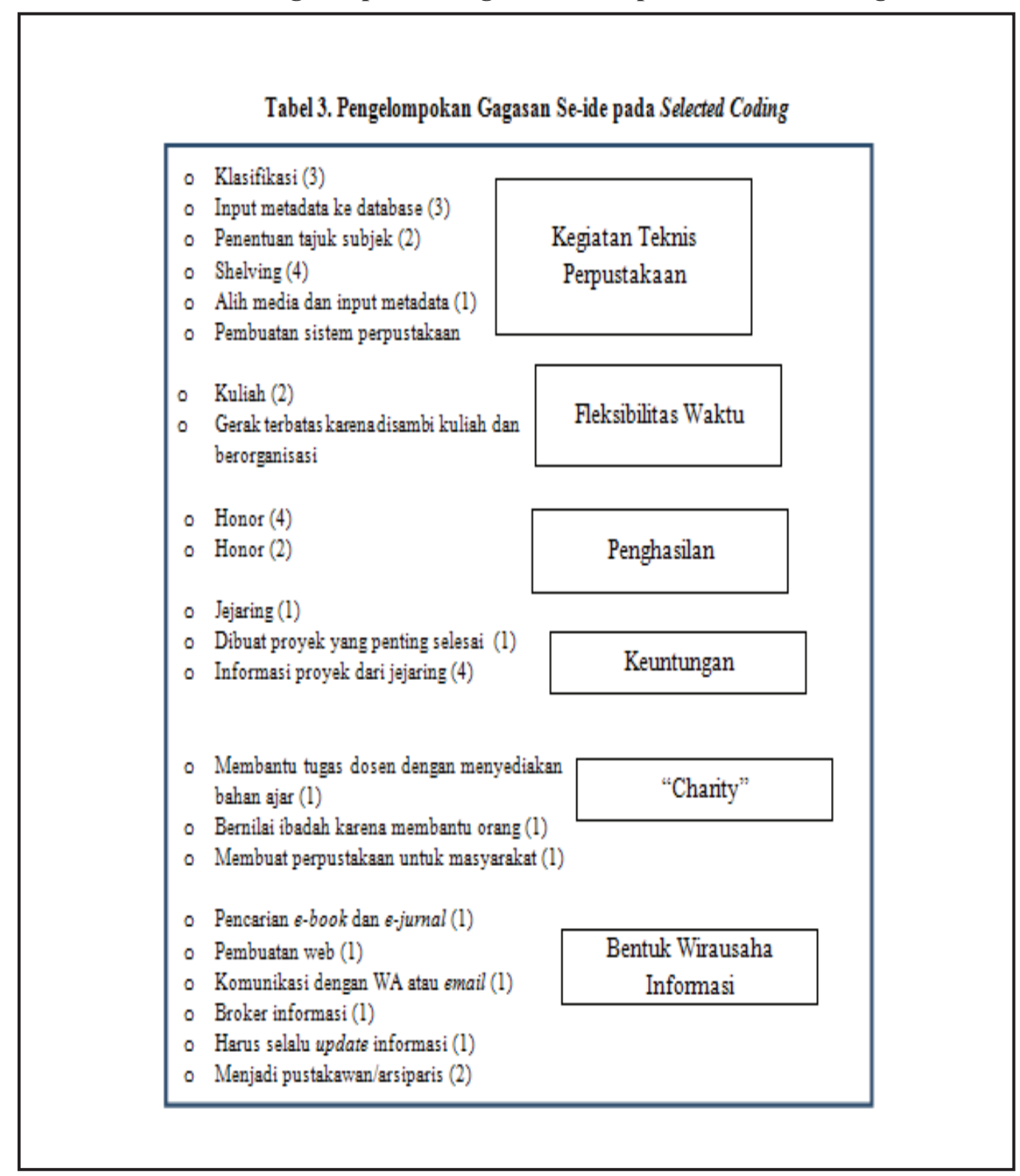

Dalam tahap selected coding, peneliti mengelompokkan gagasan-gagasan yang se-ide dalam satu kelompok. Kemudian, peneliti mencari istilah yang bisa mewakili pengelompokan tersebut, seperti yang telah diuraikan di atas. Peneliti membuat kode-kode berupa warna dan angka yang mewakili gagasan-gagasan yang se-ide tersebut.

\subsection{Diskriminan Sampling}

Untuk mengklarifikasi pengodingan yang telah peneliti buat, peneliti melakukan wawancara terhadap diskriminan sampling untuk mencari apakah ada gagasan atau ide yang baru atau ternyata menghasilkan gagasan atau ide-ide yang sama. Diskriminan sampling diambil dari responden yang berlatar belakang bukan dari ilmu perpustakaan. Tabel 4 menunjukkan hasil wawancara diskriminan sampling, mulai dari wawancara 1, wawancara 2, dan diskriminan sampling. 
Tabel 4. Wawancara 1, Wawancara 2, dan Diskriminan Sampling

\begin{tabular}{|c|c|c|}
\hline Wawancara 1 & Wawancara 2 & Diskriminan Sampling \\
\hline $\begin{array}{l}\text { A. Melakukan kegiatan } \\
\text { pengolahan } \\
\begin{array}{cl}\text { o } & \text { Klasifikasi (3) } \\
\text { o } & \text { Input metadata ke } \\
& \text { database (3) } \\
\text { o } & \text { Penentuan tajuk subjek } \\
& \text { (2) } \\
\text { o } & \text { Shelving (4) }\end{array}\end{array}$ & $\begin{array}{l}\text { A. Penelusuran bahan digital } \\
\text { Pencarian e-book dan } \\
\text { e-jurnal (1) }\end{array}$ & $\begin{array}{ll}\text { Sistem Perpustakaan } \\
\text { o } & \text { Sistem Otomasi } \\
& \text { Perpustakaan } \\
\text { o } & \text { Upgrade Sistem } \\
& \text { Perpustakaan } \\
\text { o } & \begin{array}{l}\text { Kustomisasi Sistem } \\
\end{array} \\
\text { Otomasi Perpustakaan } \\
\text { o } & \text { Ilmu dan pengalaman }\end{array}$ \\
\hline $\begin{array}{l}\text { B. Fleksibilitas waktu } \\
\begin{array}{ll}\text { o } & \text { Tidak bisa membagi } \\
& \text { waktu (2) } \\
\text { o } & \text { Kuliah (2) }\end{array}\end{array}$ & 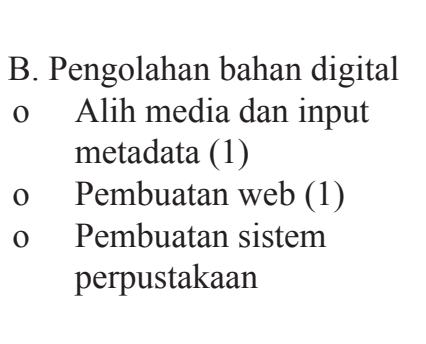 & $\begin{array}{ll}\text { o } & \text { Membuat Sistem } \\
& \text { perpustakaan } \\
\text { o } & \text { Membuat ruang baca } \\
\text { o } & \text { Menyesuaikan jadwal } \\
& \text { dengan dosen } \\
\text { o } & \text { Finansial } \\
\text { o } & \text { Channel } \\
\text { o } & \text { Dekat dengan dosen }\end{array}$ \\
\hline $\begin{array}{l}\text { C. Keterbatasan pengetahuan } \\
\qquad \begin{array}{ll}\text { o } & \text { Kesulitan menentukan } \\
& \text { subjek (2) }\end{array}\end{array}$ & 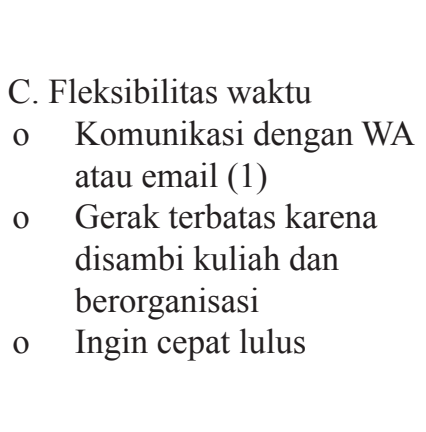 & $\begin{array}{ll}\text { o } & \begin{array}{l}\text { Direkomendasikan } \\
\text { kepada pihak lain }\end{array} \\
\text { o } & \text { Jasa sistem } \\
\text { perpustakaaan } \\
\text { o } & \text { Partner kerja } \\
\text { o } & \text { Pengolahan koleksi: } \\
& \text { inventaris, pemberian } \\
& \text { nomor kelas, labeling, } \\
& \text { stempel, entri data ke } \\
& \text { software }\end{array}$ \\
\hline $\begin{array}{l}\text { D. Penghasilan } \\
\text { o Honor (4) }\end{array}$ & $\begin{array}{ll}\text { D. } & \text { Penghasilan } \\
\text { o } & \text { Honor }(2) \\
\text { o } & \text { Jejaring (1) }\end{array}$ & $\begin{array}{ll}\text { D. } & \text { Penghasilan } \\
\text { o } & \text { Honor (2) } \\
\text { o } & \text { Kesempatan menambah } \\
& \text { relasi } \\
\text { o } & \text { Direkomendasikan ke } \\
& \text { instansi lain }\end{array}$ \\
\hline $\begin{array}{l}\text { E. Aktualisasi diri } \\
\begin{array}{ll}\text { o } & \text { Pengalaman (4) } \\
\text { o } & \text { Pengaplikasian ilmu (1) }\end{array}\end{array}$ & $\begin{array}{ll}\text { E. } & \text { Aktualisasi diri } \\
\text { o } & \begin{array}{l}\text { Dibuat proyek yang } \\
\text { penting selesai (1) }\end{array} \\
\text { o } & \begin{array}{l}\text { Membantu tugas dosen } \\
\text { dengan menyediakan }\end{array} \\
& \text { bahan ajar (1) } \\
\text { o } & \begin{array}{l}\text { Bernilai ibadah karena } \\
\text { membantu orang (1) }\end{array}\end{array}$ & $\begin{array}{ll}\text { E. } & \text { Aktualisasi Diri } \\
\text { o } & \text { Pengaplikasian ilmu } \\
\text { o } & \text { Mempraktikan hal-hal } \\
& \text { seputar perpustakaan } \\
\text { o } & \text { Memasuki era } \\
& \text { masyarakat informasi: } \\
& \text { ICT }\end{array}$ \\
\hline
\end{tabular}




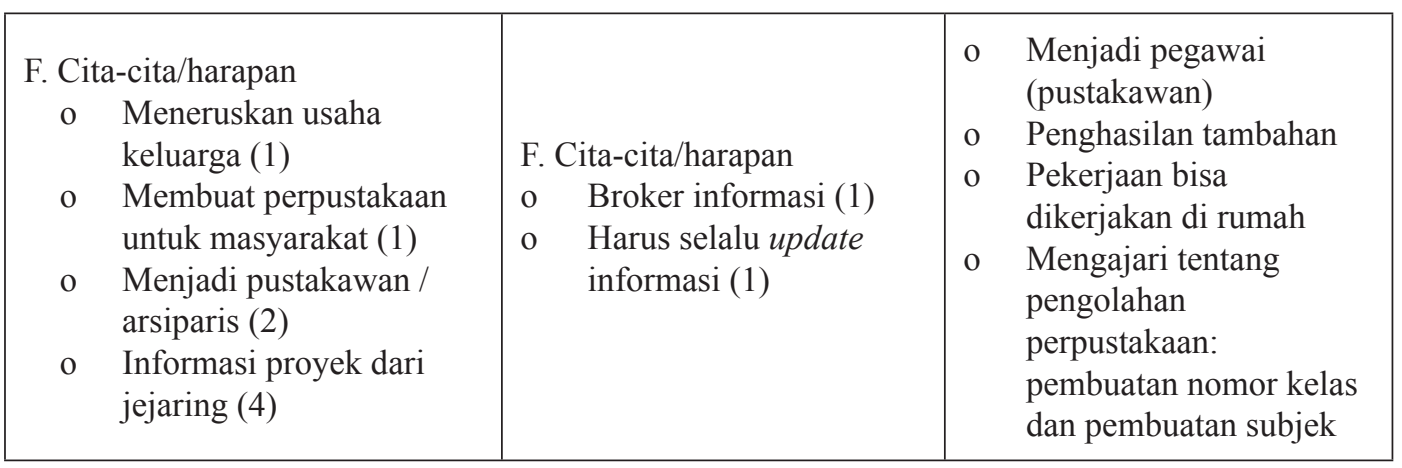

\subsection{Kategori dan Memo}

Dari pemetaan tersebut, peneliti menghasilkan kategori-kategori dan memo. Berikut ini adalah hasilnya:

Tabel 5. Kategori dan Memo dari Kegiatan Wirausaha Informasi

\begin{tabular}{|c|c|c|}
\hline No. & Kategori & Memo \\
\hline 1 & Fleksibilitas waktu & $\begin{array}{l}\text { Pekerjaannya dapat dilakukan kapan saja, waktu pekerjaan } \\
\text { bisa disesuaikan dengan waktu yang dimiliki pekerja bah- } \\
\text { kan bisa dilakukan dirumah atau ditempat lain yang memu- } \\
\text { ngkinkan. }\end{array}$ \\
\hline 2 & Penghasilan & $\begin{array}{l}\text { Wirausaha informasi memberikan penghasilan uang yang } \\
\text { memadai bagi para pelakunya. }\end{array}$ \\
\hline 3 & Keuntungan & $\begin{array}{l}\text { Selain menghasilkan uang, ternyata wirausaha informasi } \\
\text { juga memberikan keuntungan lain seperti membangun je- } \\
\text { jaring dengan pihak lain, menambah partner kerja dengan } \\
\text { pihak lain, dan ketika menghasilkan pekerjaan yang baik } \\
\text { maka mendapatkan kepercayaan atau rekomendasi ke pihak } \\
\text { lain. }\end{array}$ \\
\hline 4 & Amal & $\begin{array}{l}\text { Wirausaha informasi bukan hanya menghasilkan uang, na- } \\
\text { mun juga bisa bernilai kegiatan amal atau bernilai ibadah } \\
\text { bagi pelakunya. }\end{array}$ \\
\hline 5 & Aktualisasi diri & $\begin{array}{l}\text { Bahwa wirausaha informasi dapat menjadi wahana untuk } \\
\text { pengaplikasian ilmu dan mendapatkan pengalaman. }\end{array}$ \\
\hline 6 & $\begin{array}{l}\text { Bentuk wirausaha } \\
\text { informasi }\end{array}$ & $\begin{array}{l}\text { Adapun bentuk wirausaha informasi cukup luas mulai dari } \\
\text { menjadi pustakawan sampai kepada mengajar. }\end{array}$ \\
\hline
\end{tabular}

\subsection{Wirausaha Informasi}

Wirausaha informasi adalah pekerjaan dalam bidang informasi yang dapat dilakukan, baik secara mandiri maupun berkelompok, dengan fleksibilitas waktu dan tempat pengerjaannya, berupa kegiatan pencarian informasi, pembuatan web dan sistem perpustakaan, konsultan perpustakaan, pengajar dan pustakawan sehingga menghasilkan uang, menambah pengalaman dan ilmu serta mengembangkan aktivitas sosial". Hasil dari proses pengumpulan data dan analisis data ini adalah suatu teori. Teori tersebut muncul dari proses memoing, yang muncul dari ide tentang teori baru selama proses open, axial, dan selective coding mengenai wirausaha informasi.

Berdasarkan hasil definisi di atas, tidak ditemukan secara spesifik faktor utama yang memengaruhi mahasiswa melakukan wirausaha informasi. Namun, akan lebih baik lagi apabila mahasiswa diberikan pengetahuan mengenai pengelolaan sebuah usaha terutama agar mahasiswa memiliki pemahaman bagaimana mengatur waktu antara mengelola usaha dengan tetap menjalankan fungsinya sebagai seorang mahasiswa. Du Toit's (2000) dalam 
Ramugondo (2010: 6) mengungkapkan bahwa "motivating factors include a low economic growth rate as an enabling factor for infopreneurship". Dapat diartikan bahwa faktor ekonomi, menjadi salah satu sebab mahasiswa melakukan kegiatan wirausaha informasi. Namun, keinginan untuk merdeka adalah faktor yang paling utama bagi mahasiswa melakukan wirausaha (Aktar dan Masukujjaman, 2014). Faktor lainnya adalah locus of control dan proaktif, secara signifikan penting untuk menciptakan niat kewirausahaan. Selain itu, pendidikan kewirausahaan juga merupakan hal yang penting untuk meningkatkan tingkat pengetahuan siswa dalam proses kewirausahaan.

\subsection{Kegiatan Wirausaha Informasi}

Kegiatan wirausaha informasi sangat beraneka ragam. Berdasarkan pengalaman mahasiswa Jurusan Ilmu Perpustakaan dan Informasi Universitas Indonesia, kegiatan wirausaha informasi di antaranya pencarian informasi, pembuatan web dan sistem perpustakaan, konsultan perpustakaan, pengajar, dan pustakawan. Hal ini senada dengan Dewiyana (2006: 28) yang menyatakan bahwa "bidang pekerjaan lain yang dapat dimasuki oleh lulusan program studi perpustakaan adalah yang berkaitan dengan penanganan informasi (information handling), penelitian informasi, manajemen badan yang bergerak dalam bidang informasi seperti pada berbagai jenis perpustakaan, unit dokumentasi, unit informasi, depo arsip, pusat rekaman (arsip dinamis), dan bidang lain yang berhubungan dengan informasi baik yang bersifat nirlaba (non-profit) maupun yang berorientasi pada laba (profit oriented), perantara dan penelusur informasi, perancang-bangunan perangkat lunak khusus untuk keperluan badan pengelolaan informasi; serta bidang penerbitan dan konservasi”.

Lebih lanjut, Dewiyana (2006: 28) menyatakan "di masa mendatang, lulusan program studi perpustakaan akan dapat bekerja secara mandiri tidak harus pada organisasi perpustakaan atau unit informasi tradisional. Fenomena ini diperkirakan dapat terjadi di Indonesia khususnya di wilayah Pulau Sumatera, mengingat kerja sama ekonomi yang selalu terkait dengan kawasan ini, seperti Indonesia-Malaysia-Thailand Growth Triangle (IMT-GT), Singapura-Johor-Riau (SIJORI), dan AFTA. Ditambah lagi untuk saat ini dengan adanya Masyarakat Ekonomi ASEAN (MEA), maka wirausaha informasi akan mendapatkan tantangan dan peluangnya tersendiri yang jauh lebih besar dan kompleks.

Wirausaha informasi ini mestinya didukung dengan seperangkat kurikulum yang terdapat dalam dunia pendidikan atau perguruan tinggi. Hal ini sebagaimana dicantumkan dalam Syllabus Info ST 691 (216, 217) Special Topics in Information Science: Infopreneurship University of Wisconsin-Milwaukee School of Information Studies tahun 2014, yaitu: "1) To stimulate intrapreneurial and entrepreneurial thinking among future information professionals, 2) To develop the skills and knowledge required to identify opportunities and, through creativity and innovation, turn these opportunities into reality whether inside an already existing information-based organization or as an informationbased business, dan 3) To develop an appreciation of the impact of political, economic, social (including diversity issues), technological and legal, regulatory, and environmental factors on entrepreneurship".

Berdasarkan silabus tersebut, dapat disimpulkan bahwa perlu adanya tujuan pembelajaran infopreneurship yang termaktub dalam kurikulum perguruan tinggi pada Jurusan Ilmu Perpustakaan dan Informasi agar: 1) merangsang pemikiran intrapreneurial dan kewirausahaan di kalangan profesional informasi masa depan; 2) mengembangkan keterampilan dan pengetahuan yang diperlukan untuk mengidentifikasi peluang melalui kreativitas dan inovasi, mengubah kesempatan menjadi kenyataan di dalam mengelola informasi berbasis organisasi atau sebagai sebuah usaha berbasis informasi; dan 3) mengembangkan apresiasi dari dampak politik, ekonomi, sosial, faktor teknologi dan hukum, peraturan, dan lingkungan tentang kewirausahaan. Drew (2007:4) mengatakan bahwa "libraries can and do play roles in integrating applicable information sources and education into university curricula", ini berarti perlu dilakukan kolaborasi yang baik antara fakultas dan perpustakaan dalam mengintegrasikan teori dan penerapan ilmu dalam dunia kerja atau wirausaha. 


\section{KESIMPULAN}

Penelitian grounded theory merupakan penelitian yang menggunakan analisis yang detil. Grounded theory terdiri dari tiga fase pengodean, yaitu open coding, axial coding, dan selective coding. Penelitian ini juga memberikan pelajaran penting sebagai usaha di masa depan dalam memahami dan mengembangkan kegiatan wirausaha informasi khususnya bagi para mahasiswa Jurusan Ilmu Perpustakaan dan Informasi. Teori yang muncul dalam penelitian ini memberi pengertian tentang aksi atau proses yang terjadi dalam kegiatan wirausaha informasi. Penelitian ini menghasilkan suatu definisi tentang wirausaha informasi dari sudut pandang mahasiswa Jurusan Ilmu Perpustakaan dan Informasi Universitas Indonesia. Penelitian ini diharapkan dapat memberikan gambaran yang luas bagaimana kegiatan wirausaha informasi dari sudut pandang mahasiswa dengan harapan mahasiswa terus mengasah jiwa wirausahanya sehingga bisa menjadi bagian dari solusi pemenuhan kebutuhan dunia kerja yang luas.

\section{DAFTAR PUSTAKA}

Aktar, Serena and Masukujjaman, Md. 2014. Reasons to Create Intention of Entrepreneurship among University Students: A Study on Bangladesh. Journal of Entrepreneurship and Management, Vol. 3: 14-25.

Creswell, John W. 1998. Qualitative Inquiry and Research Design: Choosing Among Five Traditions. University of California: SAGE Publications.

Creswell, John W. 2011. Educational Research: Planning, Conducting, and Evaluating Quantitative and Qualitative Research. Boston: Pearson Education.

David, Rodreck and Dube, Adock. 2013. "Infopreneurial Behaviour Among University Graduates in the Information Science Faculty of a University in Zimbabwe". ICEE ICIT 2013 Conference. (http://ir.nust.ac.zw/xmlui/bitstream/handle/123456789/381/ Infopreneurial\%20 Behaviour\%20among\%20University.pdf?sequence $=1 \&$ isAllowed $=y$, diakses 1 Mei 2016).

Dewiyana, Himma. 2006. Kompetensi dan Kurikulum Perpustakaan: Paradigma Baru dan Dunia Kerja di Era Globalisasi Informasi. Pustaha: Jurnal Studi Perpustakaan dan Informasi, Vol.2, No.1, Juni 2006: 22-31.

Drew, Christine. 2007. “AC 2007-1063: Encouraging Use of Entrepreneurship Information Resources: Faculty/Library Collaboration". Worcester Polytechnic Institute. (https://www. wpi.edu/Images/CMS/News/1063_ENCOURAGING_USE_OF_ENTREPRENEURSHIP_ INFO.pdf, diakses 2 Mei 2016).

Khumalo, Njabulo Bruce \& Nkala, Gugulethu Shamaine. 2015. The Importance of Infopreneurship Training for Records and Archives Management Students in Zimbabwe. Journal of The South African Society of Archivists, Vol. 48: 66-76.

Lahm, Robert J. Jr \& Stowe, Charles R. B. 2010. An Exploration of Information Entrepreneurship. Proceedings of the Allied Academies Internet Conference, Volume 12: 53-56.

Mulyana, Deddy. 2001. Metodologi Penelitian Kualitatif. Bandung: Remaja Rosdakarya.

Ocholla, Dennis. 1999. Information Intermediaries in The Next Millennium: an Agenda Foraction for the Development of Information Consultancy and Brokerage in Africa. Library Management, 20 (2): 105-114.

Pendit, Putu Laxman. 2003. Penelitian Ilmu Perpustakaan dan Informasi: Sebuah Pengantar Diskusi Epistemologi dan Metodologi. Depok: JIP FSUI.

Pihie, Zaidatol Akmaliah Lope \& Sani, Abdullah Salleh Abdullah. 2009. Exploring The Enterpreneural Mindset Of Students: Implication for Improvement of Entrepreneurial Learning at University. The Journal of International Social Research, (2/8): 340-345.

Ramugondo, Lugisani S. 2010. “An Exploratory Study of Infopreneurship as A Job Option 
for Library and Information Science Students: a Literature Review". 11 ${ }^{\text {th }} D I S$ Annual Conference University of Zululand, South Africa. (http://www.lis.uzulu.ac.za/research/ conferences/2010/DIS_Conference_2010Ramagundo_reviced_version.pdf, diakses 1 Mei 2016).

Syllabus. Fall. 2014. "Special Topics in Information Science: Infopreneurship". University of Wisconsin-Milwaukee School of Information Studies (http://www4.uwm.edu/schedule/ syllabi/214937135.pdf, diakses 1 Mei 2016).

Vaghely, Ivan P. \& Julien, Pierre-André. 2010. Are Opportunities Recognized or Constructed? An Information Perspective on Entrepreneurial Opportunity Identification. Journal of Business Venturing, Vol. 25: 73-86.

Zuraida, Rida \& Ayu, K. Gita. 2013. Perilaku Berwirausaha di Kalangan Mahasiswa Universitas Bina Nusantara (BINUS). ComTech Vol. 4 No. 2 Desember: 904-913. 